\title{
Phytochemical analysis, antimicrobial and antioxidant activity evaluations of fruit of Artocarpus heterophyllus Lam
}

\author{
Sreeletha AS ${ }^{1}$, Lini JJ' ${ }^{1}$, Dhanyalekshmi CS ${ }^{2}$, Sabu KR ${ }^{3}$ and Pratap Chandran $\mathrm{R}^{4 *}$ \\ ${ }^{1}$ Department of Botany and Research Centre, Nesamony Memorial Christian College, Marthandam, Kanyakumari District, Tamil Nadu-629165, India \\ ${ }^{2}$ Biovent, KU-TBSC Start up, Department of Biotechnology, University of Kerala, Kariavattom, Thiruvananthapuram, Kerala-695 581, India \\ ${ }^{3}$ Department of Chemistry, Arba Minch University, Abaya Campus, Arba Minch, PB No. 21, Ethiopia \\ ${ }^{4}$ Department of Biotechnology and Research, K. V. M. College of Science and Technology, Kokkothamangalam PO, Cherthala-688583, Alappuzha District, Kerala \\ State, India
}

\begin{abstract}
The present study reports the fluorescence properties, phytochemical constituents, antimicrobial, and antioxidant activities of fruit flour and fruit extracts of $A$. heterophyllus in various solvents. The fluorescence properties or colours of fruit powder recorded through this study could be used as a standard to identify and authenticate the extracts of the $A$. heterophyllus fruit. The screening and study of fruit flour of $A$. heterophyllus for phytochemical constituents were performed using standard qualitative methods. The constituents obtained were carbohydrates, proteins, fats, flavonoids, phenols, carboxylic acids, coumarins, saponins and phytosterol. Proximate analysis revealed the presence of high moisture content (80\%). The dry matter contained protein (8.2\%), fat (0.4\%), carbohydrates (37\%) with a total calorific value $184.4 \mathrm{Kcal} / 100 \mathrm{~g}$. Mineral analysis showed the highest value for potassium (10.41 mg/g) and the lowest value for copper (0.0199 mg/g). Other elements like calcium $(1.31 \mathrm{mg} / \mathrm{g})$, magnesium $(0.84 \mathrm{mg} / \mathrm{g})$, phosphorus $(0.54 \mathrm{mg} / \mathrm{g})$, sodium $(0.31 \mathrm{mg} / \mathrm{g})$ and zinc $(0.36 \mathrm{mg} / \mathrm{g})$ were also present. Ethyl acetate extract showed the highest activity against Staphylococcus aureus $(16 \mathrm{~mm})$ and Candida albicans $(29 \mathrm{~mm})$. The antioxidant activity was determined using 2,2-Diphenyl-1-picryl hydrazyl (DPPH) assay for hexane, chloroform, acetone, ethyl acetate, benzene, methanol and aqueous extracts. The results showed varying degrees of free radical scavenging activity. Methanol and ethyl acetate extracts showed an $\mathrm{IC}_{50}$ value of $636.55 \mu \mathrm{g} / \mathrm{ml}$ and $713.35 \mu \mathrm{g} / \mathrm{ml} \mathrm{respectively.} \mathrm{FTIR} \mathrm{spectra} \mathrm{showed} \mathrm{the} \mathrm{presence} \mathrm{of}$ different functional groups like carboxylic, ether and C-C linkages in most of the extracts.
\end{abstract}

\section{Introduction}

Jackfruit trees belong to the family Moraceae. They grow abundantly in India, Bangladesh, and in many parts of the Southeast Asia [1]. This fruit also grows in some African countries. Jack fruit is available in Indian markets during the spring and summer seasons. The fruit contains large fleshy banana flavoured sweet bulbs which may be crispy or soft and yellow to brownish when ripe [2]. The fruit provide about $2 \mathrm{MJ}$ of energy per $\mathrm{kg} /$ wet weight of ripe fruit [3]. Jackfruit has been found to contain high level of proteins, starch, calcium and thiamine [4]. The composition of jackfruit perianth and seed has been reported [5]. Ripe fruits can be eaten raw, or cooked in creamy coconut milk as dessert, made into candied jackfruit or edible jackfruit leather. In India, jackfruit is the third largest harvested fruit ranked after mango and banana. During the season, the fruit is available in plenty and is quite cheap when ripe, but expensive in the off-season [6]. Each year approximately $30-50 \%$ the total harvested jackfruit is spoiled because of the lack of post-harvest processing in the country [7]. Besides India, jackfruit is commonly grown in home gardens of tropical and subtropical countries especially Sri Lanka, Bangladesh, Burma, Malaysia and Brazil [8]. The jackfruit is unusually large in size with a single fruit weighing up to $30-35 \mathrm{~kg}$. The ripe sweet bulbs of the fruit can be processed into ice cream, jam, jelly, alcoholic beverages, nectars and fruit powder. Jack fruit bears a compound or multiple fruit with a green to yellow brown exterior rind which is composed of hexagonal, bluntly conical carpel that covers a thick, rubbery, and whitish to yellowish interior matrix. The flesh (aril) surrounding each seed is acidic and sweetish (when ripe) with a banana like flavor and taste [9].
The fleshy interior matrix of the heavy jack fruit is held together by a central fibrous core. Fruits are oblong, cylindrical in shape, typically $30-40 \mathrm{~cm}$ in length. Large scale use of jack fruit is now attracting the attention of researchers and both seeds as well as fleshy edible arils are considered highly nutritious [10]. It is now widely accepted that the beneficial effect of many fruits is due to the presence of bioactive compounds in them [11,12]. The present study focusses on the phytochemical and proximate analyses, estimation of mineral contents, evaluation of anti-bacterial and anti-fungal activities of jack fruit extracts and flour made from jack fruit arils.

\section{Materials and methods \\ Collection of jack fruit arils}

The ripe fruits were collected from Bhagavathinada village $\left(8^{\circ} 23^{\prime} 0^{\prime \prime}\right.$ $\mathrm{N}, 77^{\circ} 5^{\prime} 0^{\prime \prime} \mathrm{E}$ ), Balaramapuram, Thiruvananthapuram district, Kerala State, India. Fruits were cleaned and cut open and its edible bulbs or

*Correspondence to: Pratap Chandran R, Department of Biotechnology and Research, K. V. M. College of Science and Technology, Kokkothamangalam PO, Cherthala-688583, Alappuzha District, Kerala State, India, E-mail: drpratapchandran@yahoo.co.in

Key words: antimicrobial, antioxidant, FTIR spectroscopy, nutritional, phytochemical

Received: September 07, 2018; Accepted: September 26, 2018; Published: October 01,2018 
arils were separated and then sliced into thin chips and shade dried. Dried pieces were finally ground and stored for further use.

\section{Chemicals used}

Distilled water, $1 \mathrm{~N} \mathrm{H}_{2} \mathrm{SO}_{4}, 1 \mathrm{~N} \mathrm{HCl}, 5 \% \mathrm{FeCl}_{3}$ solution, $\mathrm{NaOH}$ solutions of varying concentrations, $5 \% \mathrm{KOH}, \mathrm{HNO}_{3}$, methanol, ethyl acetate, acetic acid, hexane, chloroform, acetone, petroleum ether, Molisch's reagent, sulphuric acid, Wagner's reagent, ninhydrin, Muller Hinton agar, nutrient agar, potato dextrose agar, hexane, 2, 2 Diphenyl 1-picrylhydrazyl (DPPH). All chemicals used were of analytical reagent grade.

\section{Fluorescence analysis}

A number of samples were prepared separately by taking one gram of the fruit powder and mixing it thoroughly with three drops each of different solvents like methanol, acetic acid, petroleum ether, chloroform, acetone, water, and solutions such as $1 \mathrm{~N} \mathrm{NaOH,} 50 \%$ $\mathrm{HNO}_{3}, 1 \mathrm{~N} \mathrm{HCl}, 5 \% \mathrm{FeCl}_{3}, 5 \% \mathrm{H}_{2} \mathrm{SO}_{4}$ and $5 \% \mathrm{KOH}$. Then slides were prepared using these materials and observed under short UV $(254 \mathrm{~nm})$, long UV (366 nm) and visible light [13].

\section{Qualitative phytochemical analysis}

Fruit flour (1 gm) was suspended in $10 \mathrm{ml}$ of different solvents, such as hexane, chloroform, acetone, ethyl acetate, benzene, methanol and water and stirred for $24 \mathrm{~h}$ using magnetic stirrer. After 24 hours, centrifuged at 10,000 rpm for 10 minutes and the extracts were then made solvent free by rotary evaporator (IKA, RV 10 digital, Germany). The presence of phytochemicals was determined as per the standard protocol [14-16].

\section{Proximate analysis}

Dry matter and moisture contents of A. heterophyllus fruits were estimated by heating the slices of fruits at $110^{\circ} \mathrm{C}$ for $24 \mathrm{~h}$ and by finding out the difference in weight occurred. Carbohydrates, proteins and fat contents of the fruit were determined by the method of Association of Official Analytical Chemist (AOAC) [17]. pH of the 10-percentage flour suspension was checked. The calorific value in $\mathrm{Kcal} / 100 \mathrm{~g}$ was estimated using the method of FAO [18]. The energy value was determined using the formula

Energy value $(\mathrm{Kcal} / 100 \mathrm{~g})=[\%$ crude protein $\times 4.0]+[\%$ crude fat $\times 9.0]+[\%$ carbohydrate $\times 4.0]$

\section{Mineral analysis}

The mineral composition of the jackfruit flour was analysed by Inductively Coupled Plasma Atomic Emission Spectrometry (ICP-AES, Thermo Electron Iris Intrepid II XSP Duo). $1 \mathrm{~g}$ of the fruit powder was digested in $10 \mathrm{ml}$ of ultrapure metal free nitric acid in a microwave digester. After digestion, the contents were diluted to $25 \mathrm{ml}$ with distilled water. The microwave digested sample was aspirated into ICP-AES to estimate, potassium, magnesium, phosphorus, calcium, copper, zinc and sodium. The calibration standards were prepared by diluting the stock in multi elemental standard solution $(1000 \mathrm{mg} / \mathrm{l})$ in nitric acid.

\section{Microorganisms used}

Bacterial strains such as E. coli (MTCC 118), Klebsiella pneumoniae (MTCC 432), Pseudomonas aeruginosa (MTCC 424), Bacillus cereus (MTCC 430) and Staphylococcus aureus (MTCC 96) and fungal strains such as Aspergillus niger (MTCC 1344), Aspergillus flavus (MTCC 277), Pencillium chrysogenum (MTCC 160), Rhizopus oryzae (MTCC 262) and Candida albicans (MTCC 183) were tested against the fruit extracts. All microbial cultures were procured from the Microbial Type Culture Collection and Gene Bank (MTCC), Institute of Microbial Technology, Chandigarh, India. These bacterial and fungal strains were sub cultured frequently in nutrient agar and potato dextrose agar slants respectively and stored at $4^{\circ} \mathrm{C}$ for further studies.

\section{Antibacterial assay}

The antibacterial sensitivity assay was carried out by disc diffusion method [19] and different solvent extracts of the fruits were tested against the selected bacterial strains mentioned above. The bacterial cultures were evenly spread over Mueller Hinton agar plates using a sterile cotton swab. The sterile discs (6 $\mathrm{mm}$ in diameter) were impregnated with extract solution and placed in the inoculated agar. The plates were then incubated at $37^{\circ} \mathrm{C}$ for 24 hours. After incubation, the zones of inhibition developed were measured with a scale to the nearest $\mathrm{mm}$. The experiments were done in triplicates and the mean values were taken.

\section{Antifungal Assay}

Antifungal activity was measured using disc diffusion method [19]. The fungal cultures to be tested were evenly spread over potato dextrose agar plates using sterile cotton swab. Then, sterile paper discs $(6 \mathrm{~mm}$ diameter) impregnated with different solvent extracts was placed on agar plate. Inhibition zones were determined after incubation at $25^{\circ} \mathrm{C}$ for 48 hours. All tests were done in triplicate and the mean values are presented.

\section{Determination of antioxidant activity}

The free radical scavenging activity of fruit extracts at different concentrations were measured from the decolourisation of the purple colour of 2, 2-Diphenyl-1-picryl hydrazyl (DPPH) [20]. Hexane, chloroform, acetone, ethyl acetate, benzene, methanol and aqueous extracts were tested for antioxidant activity. About $0.1 \mathrm{ml}$ solution of different concentrations of extracts were added to $1.4 \mathrm{ml}$ of DPPH and kept in dark for $30 \mathrm{~min}$. The absorbance was measured at 517 $\mathrm{nm}$ (Shimadzu UV/VIS NIR 3600) and the percentage inhibition was calculated using the following equation,

Percentage inhibition $(\%)=(\mathrm{A} 0-\mathrm{A} 1) / \mathrm{A} 0 \times 100$,

where $\mathrm{A} 0$ is the absorbance of the control and $\mathrm{A} 1$ the absorbance of the test solution. The results can also be expressed in terms of $\mathrm{IC}_{50}$ value which is the effective concentration at which the antioxidant activity is $50 \%$. BHA was used as the standard antioxidant.

\section{Fourier transform infrared spectroscopic analysis (FTIR)}

In a typical analysis, $2 \mathrm{mg}$ of the sample was mixed with $100 \mathrm{mg}$ $\mathrm{KBr}$ (FT-IR grade) and then compressed to prepare sale-disc ( $3 \mathrm{~mm}$ diameter). The disc was immediately put into the sample holder and a FTIR spectrum was recorded in the absorption range between 400 and $4000 \mathrm{~cm}^{-1}$. All investigations were carried out using Thermo Nicolet, Avatar 370 FT-IR spectroscopy.

\section{Results and discussion}

\section{Fluorescence analysis}

The characteristic fluorescence or colours emitted by the powdered sample of fruit before and after treating with various reagents were recorded. After treating with various reagents as shown in Table 1, as $\mathrm{FeCl}_{3}$, the powder showed black, white and yellow colours at different 
Table 1. Fluorescence analysis of A. heterophyllus flour

\begin{tabular}{|c|c|c|c|}
\hline Chemical/solvent & Visible light & Short UV & Long UV \\
\hline Powder as such & Yellow & Yellow & White \\
\hline Methanol & Yellow & Yellow & White \\
\hline Acetic acid & Yellow & Yellow & White \\
\hline Petroleum ether & Yellow & Yellow & White \\
\hline Water & Yellow & White & White \\
\hline $1 \mathrm{~N} \mathrm{NaOH}$ & Yellow & Yellow & Yellow \\
\hline $50 \% \mathrm{HNO}_{3}$ & Yellow & Yellow & Yellow \\
\hline $1 \mathrm{~N} \mathrm{HCl}^{\mathrm{H}} \mathrm{FeCl}$ & Yellow & Yellow & White \\
\hline $\mathrm{Chloroform}$ & Yellow & Yellow & Black \\
\hline Acetone & Yellow & Yellow & White \\
\hline $5 \% \mathrm{H}_{2} \mathrm{SO}_{4}$ & Yellow & Yellow & White \\
\hline $5 \% \mathrm{KOH}$ & Yellow & Yellow & White \\
\hline
\end{tabular}

wavelengths. The characteristic fluorescence or colours recorded in this study could be used as a standard in the identification and authentication of the A. heterophyllus fruit powder or extracts (Table 1).

The fruit powders exposed to UV at $254 \mathrm{~nm}$ and $366 \mathrm{~nm}$ produced different colours during fluorescent analysis. The purity of various plant products in crude form can be measured using fluorescent spectroscopy and could be used as a standard for identification and authentication [21,22].

\section{Phytochemical analysis}

The results obtained showed that methanol extract and aqueous extract have the presence of carbohydrates while fat content was detected only in the case of latter. Secondary metabolites like alkaloids, quinine and xanthoproteins were absent in all the extracts tested. Singh et al. [23] have reported that raw and ripe seeds were rich in phenolics compared to ripe bulbs (arils) covering the seed. Acetone extract showed the presence of flavanoids and coumarin. The presence of phytochemicals in different extracts is given in Table 2.

\section{Proximate analysis and mineral composition}

Proximate analysis of the fruit flour showed the presence of a significant amount of moisture, carbohydrates, proteins and fats. Also, the powder showed an energy content of 184.4 (Kcal/100 g) and the proximate compositions obtained are given in the Table 3. Moisture content is an index of the storage stability of the flour and it generally depends on the duration and temperature of drying. The lower the moisture content of the flour, better is its shelf life and hence a sustained quality. We found an average moisture content of approximately 80 percentage in the fruit flour, which is closer to the reported value [24,25].

Dry matter content in the fruit powder was $19.7 \%$. This is more or less comparable to the reported value of $19.16 \%$ [26,27]. The variations in the dry matter contents can be due to the fluctuations in climatic and soil conditions. The percentage of protein content in the powder was found to be $8.2 \%$ whereas the values reported by Ocloo et al. [28] and Kumar et al. [29] are 13.5 and 17.8 percentage respectively. Similarly values of $6.34-8.57 \%$ have also been reported for jackfruit seed flour [30]. The wide difference in protein content observed may be attributed to varietal differences, extent of maturation of the seeds and variations in environmental conditions.

Fat content of the A. heterophyllus fruit was $0.4 \%$ and this was similar to the reported fat content of $0.1-0.4 \%$ [31]. The major component of the fruit flour was carbohydrates, $37 \%$. The observed value was higher than the values (16-25.4\%) reported by Swami et al. [32]. The calorific value observed in the present study $184.4 \mathrm{Kcal} / 100$ $\mathrm{g}$, which is almost double the value reported by Zeisel [33]. However, a still higher value, $292-313 \mathrm{~K} \mathrm{cal} / 100 \mathrm{~g}$ was reported by Akinmutimi [34]. $\mathrm{pH}$ of the fruit flour obtained by us was 6.3. The level of $\mathrm{pH}$ is generally used to estimate the quality of the flour. The observed $\mathrm{pH}$ value in the present study is more towards the neutral point compared to the findings of Albi and Jayamutshunagai [2], where it was 5.7.

Mineral composition of $A$. heterophyllus fruit flour is given in Table 3. ICP-AES studies showed that fruit flour of A. heterophyllus is rich in potassium $(10.41 \mathrm{mg} / \mathrm{g})$, calcium $(1.31 \mathrm{mg} / \mathrm{g})$ followed by magnesium $(0.84 \mathrm{mg} / \mathrm{g})$ and sodium $(0.31 \mathrm{mg} / \mathrm{g})$. Jack fruit was also found to be an important source of copper $(0.0119 \mathrm{mg} / \mathrm{g})$ and zinc $(0.362 \mathrm{mg} / \mathrm{g})$. Swami et al. [32] revealed that bulb of jack fruit contains $21 \mathrm{mg} / \mathrm{g}$ potassium, $37 \mathrm{mg} / \mathrm{g}$ magnesium and $0.42 \mathrm{mg} / \mathrm{g}$ zinc. The differences in mineral contents observed in our study could be attributed to the variety of jackfruit and the geographical location of plant. Potassium seems to be the major mineral content in A. heterophyllus fruits and there exist reports of previous studies that food rich in potassium helps in lowering blood pressure [35]. Previous studies showed that jackfruit seed flour has the highest amount of potassium $(4.66 \mathrm{mg} / \mathrm{g})$, calcium $(0.9 \mathrm{mg} / \mathrm{g})$ and sodium $(0.25 \mathrm{mg} / \mathrm{g})$ [34]. Higher contents of calcium $(3.087 \mathrm{mg} / \mathrm{g})$, magnesium $(3.38 \mathrm{mg} / \mathrm{g})$ and potassium $(14.781 \mathrm{mg} / \mathrm{g})$ in jack fruits were also reported earlier [30].

\section{Antibacterial activity}

This study revealed that $A$. heterophyllus fruit extracts showed broad spectrum of antibacterial activity. The highest zone of inhibition $19 \mathrm{~mm}$ was developed against $S$. aureus by the aqueous extract and the lowest zone of inhibition of $7 \mathrm{~mm}$ were observed for hexane extract against E. coli. All the solvent extracts showed antibacterial activity against $S$. aureus except hexane extract. The antibacterial activities exhibited by different solvent extracts are given in Table 4. Khan et al. [36] studied the antibacterial activity of methanolic extracts of $A$. heterophyllus fruits

Table 2. Phytochemical screening of A. heterophyllus fruit extracts

\begin{tabular}{|c|c|c|c|c|c|c|c|}
\hline Test & Hexane & Chloroform & Acetone & $\begin{array}{c}\text { Ethyl } \\
\text { Acetate }\end{array}$ & Benzene & Methanol & $\begin{array}{c}\text { Distilled } \\
\text { water }\end{array}$ \\
\hline Carbohydrates & + & + & - & - & + & + & + \\
\hline Protein & - & + & - & - & + & - & + \\
\hline Fat & - & - & - & - & - & - & + \\
\hline Alkaloid & - & - & - & - & - & - & - \\
\hline Phenol & - & - & - & + & - & + & - \\
\hline Flavanoids & - & + & + & - & - & - & + \\
\hline Phytosterol & - & - & - & - & + & + & - \\
\hline Quinone & - & - & - & - & - & - & - \\
\hline Xanthoprotein & - & - & - & - & - & - & - \\
\hline Coumarin & - & - & + & - & - & - & - \\
\hline $\begin{array}{c}\text { Carboxylic } \\
\text { acid }\end{array}$ & - & - & - & - & - & + & - \\
\hline Saponin & + & - & - & - & - & + & + \\
\hline
\end{tabular}

Table 3. Proximate analysis and mineral composition of $A$. heterophyllus fruit flour

\begin{tabular}{|c|c|c|c|}
\hline Major components & Weight $(\%)$ & Minerals & Quantity $(\mathrm{mg} / \mathrm{g})$ \\
\hline Moisture & 80 & Calcium $(\mathrm{Ca})$ & 1.31 \\
\hline Dry matter & 19.7 & Potassium $(\mathrm{K})$ & 10.41 \\
\hline Protein & 8.2 & Magnesium $(\mathrm{Mg})$ & 0.84 \\
\hline Fat & 0.4 & Phosphorus $(\mathrm{P})$ & 0.54 \\
\hline Carbohydrates & 37 & Sodium $(\mathrm{Na})$ & 0.31 \\
\hline Energy (Kcal/100g) & 184.4 & Zinc $(\mathrm{Zn})$ & 0.36 \\
\hline $\mathrm{pH}$ & 6.3 & Copper $(\mathrm{Cu})$ & 0.01 \\
\hline
\end{tabular}


and reported a broad spectrum of antibacterial activity. Crude extracts and phytochemicals isolated from A. heterophyllus fruits have been found to have antibacterial activity [36,37].

\section{Antifungal activity}

Ethyl acetate extract of A. heterophyllus fruit flour showed activity against all the fungal species studied. A zone of inhibition of $12 \mathrm{~mm}$ was noted against Aspergillus niger for aqueous extract. The largest zone of inhibition of $29 \mathrm{~mm}$ was observed against C. albicans in ethyl acetate extract. Chloroform extract produced a zone of inhibition of 25 $\mathrm{mm}$ against $R$. oryzae and C. albicans. Hexane extract showed negative result for all fungal species tested except $P$. chrysogenum. Madhavi et al. [38] studied the antifungal activity of jack fruit latex and reported that the methanolic and chloroform extracts of fruit latex did not have any activity against $A$. niger, A. flavus and C. albicans at $12.5 \mathrm{mg} / \mathrm{ml}$ concentration. At $100 \mathrm{mg} / \mathrm{ml}$ concentration, the extracts produced 14, 16 and $13 \mathrm{~mm}$ zones of inhibition which was similar to the present observation. The results of the antifungal studies for different solvent extracts are given in Table 5.

\section{Antioxidant activity}

Results of the free radical scavenging experiments performed using different extracts with respect to DPPH neutralisation is given in the Figure $1(\mathrm{a}-\mathrm{c})$. DPPH is a stable free radical with characteristic absorption at $517 \mathrm{~nm}$. The extent of neutralisation of the DPPH radicals was determined by the decrease in absorbance at $517 \mathrm{~nm}$, where a change in colour to yellow denotes quenching of free radicals by various extracts. Methanol and ethyl acetate extract of $A$. heterophyllus fruit showed the highest activity with an $\mathrm{IC}_{50}$ value of $636.55 \mu \mathrm{g} / \mathrm{ml}$ and $713.36 \mu \mathrm{g} / \mathrm{ml}$ respectively. Hexane extract exhibited the lowest activity. Soong and Barlow [39] have previously reported the highest antioxidant activity and the presence of phenolic contents in the edible portions of $A$. heterophyllus fruit.

\section{Fourier transform infrared spectroscopic analysis}

FTIR spectrum gives an idea about the functional groups present in a compound. There are several stretching and bending vibrations in the IR spectrum of extracts of $A$. heterophyllus fruit. The IR spectra of both seeds and fruits showed various vibrations (wave numbers) between $4000-650 \mathrm{~cm}^{-1}$. The results of FTIR analysis done on various extracts of heterophyllus fruit are given in Figure 2.
In the case of ethyl acetate extract of A. heterophyllus fruits, the absorption band at $3342 \mathrm{~cm}^{-1}$ is very broad and is typical of moisture. The wave number $1740 \mathrm{~cm}^{-1}$ is due to contamination from the solvent used i.e., ethyl acetate; Similarly, those at $1377 \mathrm{~cm}^{-1}, 1238 \mathrm{~cm}^{-1}$ and $1048 \mathrm{~cm}^{-1}$ are due to ethyl acetate. Transmission band at $1639 \mathrm{~cm}^{-1}$ represents the free carboxyl groups in pectin. It is a carbohydrate which is a polysaccharide. The wave number at $1104 \mathrm{~cm}^{-1}$ is due to the carbohydrate structure (polysaccharide) which can be either R-O-R or a cyclic $\mathrm{C}-\mathrm{C}$ bond.

From the IR spectrum of methanol extract of the fruit, it was observed that the broader peaks at $3269 \mathrm{~cm}^{-1}$ and $2929 \mathrm{~cm}^{-1}$ are due to moisture and some carboxylic acid groups respectively. The wave number corresponding to peak of $628 \mathrm{~cm}^{-1}$ can be due to free carboxyl groups in perulic acid. Other wave numbers below $1350 \mathrm{~cm}^{-1}$ up to $1000 \mathrm{~cm}^{-1}$ (or $998 \mathrm{~cm}^{-1}$ ) usually are found along with pectin which is a polysaccharide with varying degrees of esterification.

Similarly the spectra of aqeous extract of A.heterophyllus fruit showed the following wave numbers: the vibrations at $3286 \mathrm{~cm}^{-1}$ is due to moisture. The wave number $1639 \mathrm{~cm}^{-1}$ is due to free carboxyl groups in pectin. The remaining transmission bands below $1200 \mathrm{~cm}^{-1}$ corresponds to the finger print region of carbohydrates lkle polysaccharides which can be ether linkage i.e., R-O-R or cyclic C-C bond.

FTIR spectrum of jackfruit seed in its powdered form was studied by Barua and Boruah [40]. Two hitherto undetected elements such as manganese and magnesium were confirmed during their analysis. Some specific wave numbers were also observed by them and were not assigned to any specific functional groups. Therefore, further studies are to be conducted for the identification of these functional groups [41]. Nanosized particles of jackfruit seeds were also studied using FTIR [42].

Recently our research group studied the FTIR spectra of extracts of A. heterophyllus seeds in various solvents [43]. According to this study, the FTIR spectra of ethyl acetate extract of A. heterophyllus seed showed major vibrations at wave numbers like $1740 \mathrm{~cm}^{-1}, 1377 \mathrm{~cm}^{-1}, 1243 \mathrm{~cm}^{-1}$ and $1048 \mathrm{~cm}^{-1}$ which are due to traces of the solvent used i.e., ethyl acetate. This does not show the existence of pectin (i.e. no vibrations at $1639 \mathrm{~cm}^{-1}$ or $1649 \mathrm{~cm}^{-1}$ ) which is normally expected. The wave numbers in the beginning around $2985-2929 \mathrm{~cm}^{-1}$ are due to some carboxylic acid groups, which could be attributed to the low degree of esterification.

Table 4. Antibacterial activity of extracts of A. heterophyllus fruit flour

\begin{tabular}{|c|c|c|c|c|c|c|c|}
\hline \multirow{2}{*}{ Bacteria } & \multicolumn{4}{|c|}{ Zone of inhibition (in mm) of different solvent extracts (- no activity) } \\
\cline { 2 - 6 } & Hexane & Chloroform & Ethyl acetate & Acetone & Benzene & Methanol & Distilled water \\
\hline E. coli & $7 \pm 0.1$ & $11 \pm 0.2$ & $14 \pm 0.26$ & $10 \pm 0.05$ & $12 \pm 0.22$ & - \\
\hline Klebsiella pneumonia & - & $8 \pm 0.1$ & $17 \pm 0.16$ & - & - \\
\hline $\begin{array}{c}\text { Pseudomonas } \\
\text { aeruginosa }\end{array}$ & - & $13 \pm 0.16$ & $8 \pm 0.23$ & - & - \\
\hline Bacillus cereus & - & $18 \pm 0.1$ & $10 \pm 0.05$ & - & - \\
\hline $\begin{array}{c}\text { Staphylococcus } \\
\text { aureus }\end{array}$ & - & $8 \pm 0.1$ & $16 \pm 0.25$ & $14 \pm 0.25$ & - \\
\hline
\end{tabular}

Table 5. Antifungal activity of extracts of A. heterophyllus fruit flour

\begin{tabular}{|c|c|c|c|c|c|c|c|}
\hline \multirow{2}{*}{ Fungi } & \multicolumn{7}{|c|}{ Zone of inhibition (in $\mathrm{mm}$ ) of different solvent extracts (- no activity) } \\
\hline & Hexane & Chloroform & Ethyl acetate & Acetone & Benzene & Methanol & Distilled water \\
\hline Aspergillus niger & - & - & $2 \pm 0.1$ & - & $8 \pm 0.11$ & $1 \pm 0.2$ & $12 \pm 0.05$ \\
\hline Aspergillus flavus & - & $5 \pm 0.21$ & $1 \pm 0.2$ & - & - & - & - \\
\hline Pencillium chrysogenum & $13 \pm 0.15$ & - & $14 \pm 0.25$ & $15 \pm 0.11$ & $1 \pm 0.2$ & - & - \\
\hline Rhizopus oryzae & - & $25 \pm 0.15$ & $18 \pm 0.1$ & $14 \pm 0.2$ & $24 \pm 0.15$ & - & - \\
\hline Candida albicans & - & $25 \pm 0.2$ & $29 \pm 0.2$ & $14 \pm 0.1$ & $23 \pm 0.2$ & - & - \\
\hline
\end{tabular}




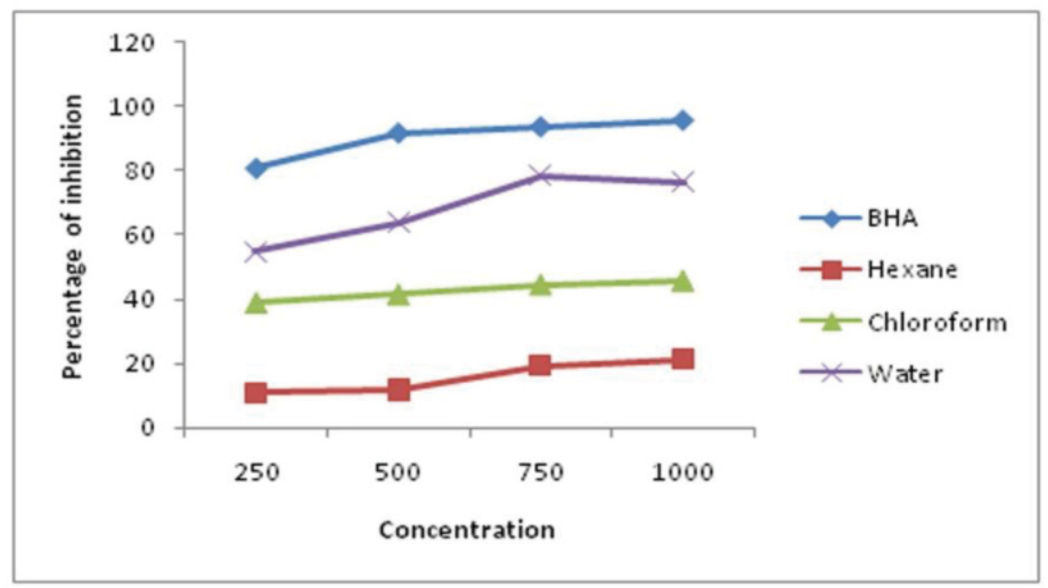

a. DPPH radical scavenging activity of hexane, chloroform and aqueous extracts

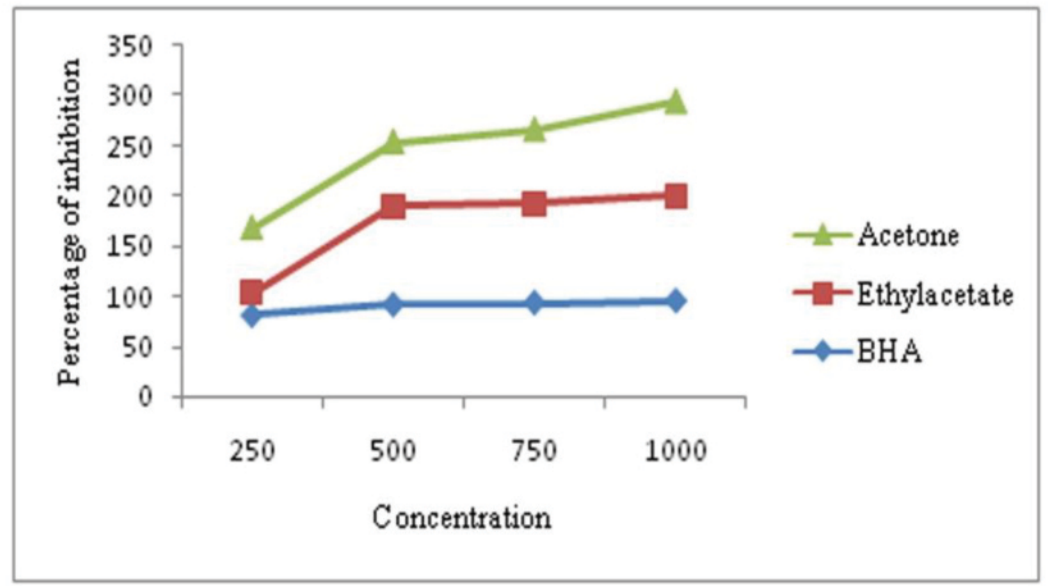

b. DPPH radical scavenging activity of ethyl acetate and acetone extracts

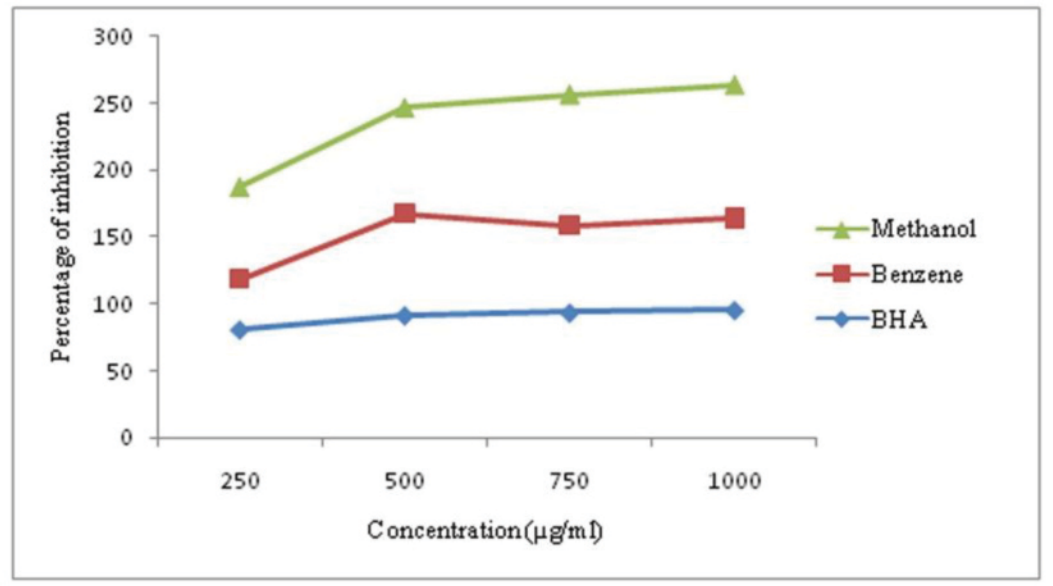

c. DPPH radical scavenging activity of methanol and benzene extracts

Figure 1 (a-c). DPPH radical scavenging activity of different extracts 


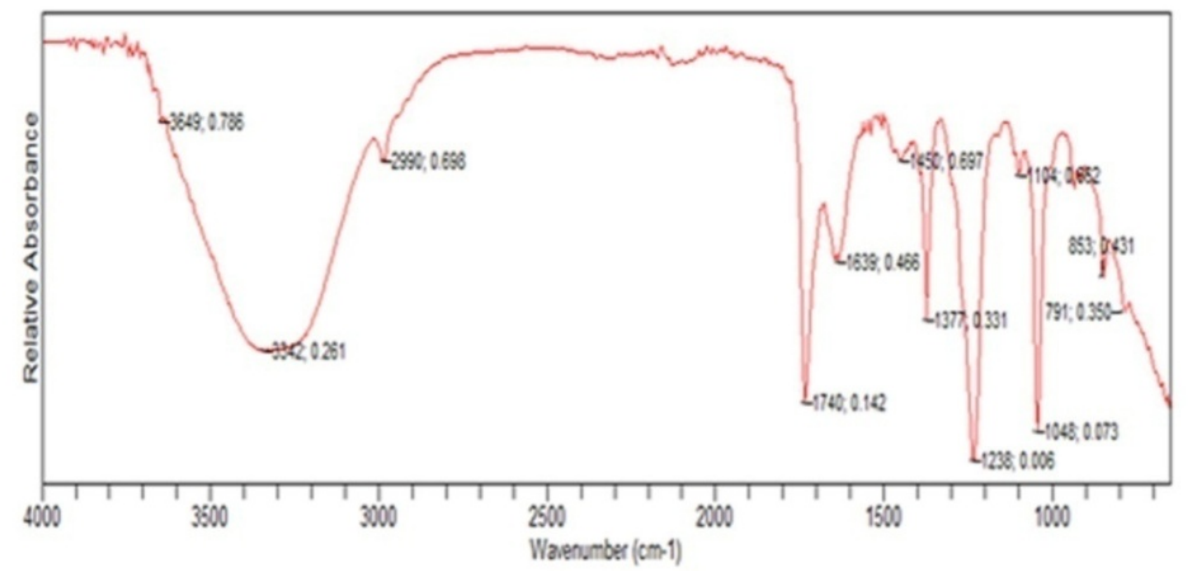

FTIR spectrum of ethyl acetate ex tract

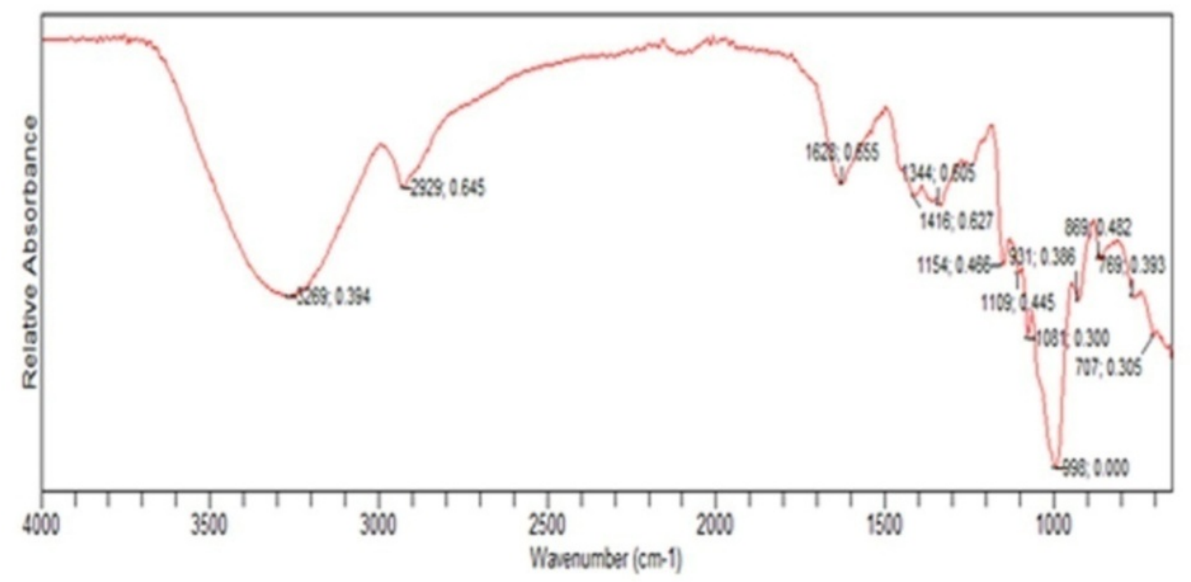

FTIR spectrum of methan ol extract

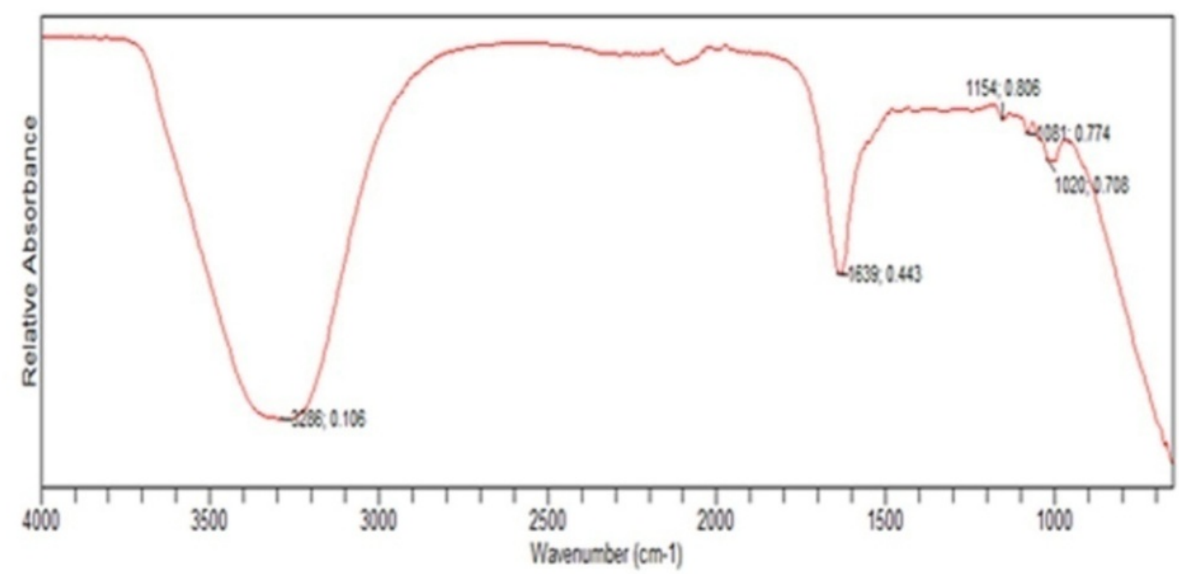

FTIR spectrum of aqueous ex tract

Figure 2. FTIR spectra of different extracts 


\section{Conclusions}

The present study established the significance of A. heterophyllus fruit as a source for medicinally important compounds: besides this edible fruit is a store house of minerals, vitamins, antioxidant and other nutrients. The antioxidant constituents present in the fruit plays an important role in scavenging free radicals which are responsible for a number of disorders. A. heterophyllus fruits and fruit products hold potential in the diet as they are palatable, readily available source of instant energy and are also antibacterial and antifungal in action.

\section{Acknowledgements}

The authors are thankful to Sophisticated Test and Instrumentation Centre, Cochin, Kerala State, India, for carrying out the elemental analysis.

\section{References}

1. Rahman MA, Nahar N, Mian AJ, Mosuthuzzaman M (1999) Variation of Carbohydrate composition of two forms of fruit from jack tree with maturity and climatic conditions. Food Chem 65: 91-97.

2. Albi A, Jayamuthunagai H (2014) An analytical study on Jackfruit seed flour and its incorporation in pasta. Res J Pharm Bio Chem Sci 5: 1597-1610.

3. Ahmad M, Irsha, Rizvi MA (2011) Nutritional and medicinal potential of Lagenaria siceraria. Int J Vegetable Sci 7: 157-170.

4. Burkill HM (1997) The useful plants of West tropical Africa. Royal Botanic Garden, Kew 2: 160-161.

5. Bobbio FO, Eldash AA, Rodhgues LR (1978) Isolation and characterization of the physico-chemical proportion of the starch of jack fruit seed. Cereal Chem 64: 505-514.

6. Jagtap SN, Bapat VA (2010) Evaluation of antioxidant capacity and phenol content in jackfruit (Artocarpus heterophyllus Lam.) fruit pulp. Plant Foods Hum Nutr 65: 99-104.

7. Ali N (2003) Post-harvest technology for employment generation in rural section of India. Central Institute of Agricultural Engineering, Indian Council of Agricultural Research, India. 63-105.

8. Jagadeesh SL, Reddy BS, Swamy GSK, Gorbal K, Hedge L, Kajjidoni ST (2007) Chemical composition of jackfruit (Artocarpus heterophyllus Lam.) selection of Western Ghats of India. Food Chem 102: 361-365.

9. Elevitch CR, Manner HI (2006) Artocarpus heterophyllus (jackfruit). In: Species profiles for Pacific Island agroforestry.

10. Prakash O, Kumar R, Mishra A, Gupta R (2009) Artocarpus heterophyllus (Jackfruit): An overview. Pharmacog Reviews 3: 353-358.

11. Galaverna G, Di Silvestro G, Cassano A, Sforzaa S, Dossena A, et al. (2008) A new integrated membrane process for the production of concentrated blood orange juice: effect on bioactive compounds and antioxidant activity. Food Chem 106: 1021-30.

12. Vinuda MM, RuizNY, Fernandez LJ, Perez AJA (2010) Spice as a functional food; a review. Crit Rev Food Sci Food saf 9: 240-58.

13. Kokkoshi CJ, Kokoski RJ, Slama FJ (1958) Fluorescence of powdered vegetable drugs under ultraviolet radiation. J Am Pharm Assoc Am Pharm Assoc 47: 715-717. [Crossref]

14. Sofowara A (1993) Medicinal plants and traditional medicine in Africa. Spectrum Books Ltd, Ibadan, Nigeria 289: 15.

15. Trease GE, Evans WC (1989) Pharmacognosy. Bailliere Tindall, London, 11: 45-50.

16. Chandran PR (2017) Analysis of Proximate, Phytochemical, Elemental Compositions and Antioxidant Property of Leaf of Alternantherabrasiliana (L.) Kuntze. MOJ Food Proc Technol 4: 00090.

17. AOAC (2000) Official Methods of Analysis. Association of official analytical chemists, Washington 17.

18. FAO (2003) Food energy methods of analysis and conversion factors. Food and Nutrition Paper, Rome, Italy 77: 1-93.

19. Bauer AW, Kirby WM, Sherris JC, Turck M (1996) Antibiotic susceptibility testing by a standardized single disk method. Am J Clin Pathol 45: 493-496.

20. Coruh N, Sagdicoglucelep AG, Ozgokce F (2007) Antioxidant properties of Prangos ferulacea (L.) Lindl., Chaerophyllum macropodum Boiss. And Heracleum persicum
Desf. From Apiaceae family used as food in Eastern Anatolia and their inhibitory effects on glutathione-S-transferase. Food Chem 100: 1237-1242.

21. Chandran RP, Vysakhi MV, Manju S, Kannan M, Kadar AS (2013) In vitro free radical scavenging activity of aqueous and methanolic leaf extracts of Aegle tamilnadensis Abdulkader (Rutaceae). Int J Pharm Pharm Sci 5: 819-823.

22. Adediwura FJ, AyotundeA (2012) Phytochemical and pharmacognostic studies of Telosma africanum (NEBr) colville leaf and stem. Int J Pharm Sci Res 3: 1860-1862.

23. Singh A, Maurys S, Singh M, Singh UP (2015) Studies on the phenolic acid contents in different parts of raw and ripe jackfruit and their importance in human health. Int J Appl Sci Res Rev 2: 36-40.

24. Haq N (2006) Jackfruit (Artocarpus heterophyllus). In: Tropical fruit trees. Southampton Centre for underutilised crops, University of Southampton.

25. Purglove JW (1968) Tropical crops. Dicotyledons Longmans. Greeen and Co. Ltd. London, pp: 377-390.

26. Karim MR, Haque MA, Yasmin L, Uddin M, Haque AHMM (2008) Effect of harvesting time and varieties on the physicochemical characteristics of jackfruits (Artocarpusheterophyllus Lam.). Int J Sustain Crop Prod 3: 48-57.

27. Popenoe W (1974) Manual of tropical and Subtropical Fruits. Hafner press. Iv. of MacMillon publishing Co. Inc, pp: 413-414.

28. Ocloo FCK, Bansa D, Boatin R, Adom T, Agbemavor WS (2010) Physico-chemical, functional and pasting characteristics of flour produced from jackfruits seeds. Agric Biol J North Am 5: 903-908.

29. Kumar S, Singh AB, Abidi AB, Upadhyay RG, Singh A (1988) Proximate composition of jack fruit seeds. J Food Sci Tech 25: 308-309.

30. Mukprasirt A, Sjjaanantaku K (2004) Physico- chemical properties of flour and starch from jackfruit seeds compared with modified starches. Int J Food Sci Tech 39: 271-276.

31. Gunasena HPM (1993) Documentary survey on Artocarpus heterophyllus (Jackfruit). Forest Information Service, Forest Department, pp: 59.

32. Swami SB, Swami NJ, Haldankar PM, Kalse SB (2012) Jackfruit and its many functional components as Related to Human health: A Review. Compr Rev Food Sci Food Saf 11: 565-576.

33. ZeiselSH (1990) Regulation of nutraceutical. J Sci Indus Res 285: 1853-1855.

34. Akinmutimi $\mathrm{AH}$ (2006) Nutritive value of raw and processed jack fruit seeds (Artocarpus heterophyllus) chemical analysis. Agric J 1: 266- 271.

35. Smith SR, Klotman PE, Svetkey LP (1992) Potassium chloride lowers blood pressure and causes natriuresis in older patients with hypertension. J Am Soc Nephrol 2: $1302-$ 1309. [Crossref]

36. Khan MR, Omoloso AD, Kihara M (2003) Antibacterial activity of Artocarpus heterophyllus. Fitoterapia 74: 501-505. [Crossref]

37. Sato M, Fujiwara S, Tsuchiya H, Fujii T, Iimuna M, et al. (1996) Flavones with antibacterial activity against cariogenic bacteria. J Ethnopharmacol 54: 171-176. [Crossref]

38. Madhavi Y, Raghava CH, Ravikiran D, Raghava (2013) Studies on phytochemical analysis and antimicrobial activity of Artocarpus heterophyllus fruit latex against selected pathogenic microorganisms. Int J Sci Eng Res 4: 1458-1468.

39. Soong YY, Barlow PJ (2004) Antioxidant activity and phenolic content of selected fruit seeds. Food Chem 88: 411-417.

40. Barua AG, Boruah BR (2004) Minerals and functional groups present in the jackfruit seed: a spectroscopic investigation. Int J Food Sci Nutr 55: 479-483. [Crossref]

41. Starlin T, Arulraj C, Ragavendhran P, Gopalakrishnan VK (2012) Phytochemical screening, functional groups and elemental analysis of Tylophora pauciflora Wight and Arn. Int Res J Pharma 3: 180-183.

42. Theivasanthi T, Venkadamanickam G, Palnivelu M, Alagar M (2011) Nanosized powder of jackfruit seed: spectroscopic and antimicrobial investigative approach. Nano Biomed Eng 3: 215-221.

43. Sreeletha A S, Lini JJ, Dhanyalekshmi CS, Sabu KR, Chandran PR (2017) Proximate, Mineral, Antioxidant and FTIR Analyses of Seeds of Artocarpus heterophyllus Lam. Adv Biotechnol Microbiol 5: 555-653.

Copyright: (C2018 Sreeletha AS. This is an open-access article distributed under the terms of the Creative Commons Attribution License, which permits unrestricted use, distribution, and reproduction in any medium, provided the original author and source are credited. 